\title{
Analysis of the Green Turtle Esophagus Chelonia Mydas (Linnaeus, 1758), Testudines, Cheloniidae
}

\author{
Análisis del Esófago de la Tortuga Verde Chelonia \\ mydas (Linnaeus, 1758), Testudines, Cheloniidae
}

\begin{abstract}
Luana Félix De Melo ${ }^{1,4}$; Ana Clara Bastos Rodrigues ${ }^{1}$; Marisol León Cabrera ${ }^{1}$; Anaelise de Oliveira Macedo Turquetti'; Lourenço Proença Ruivo²; Gabriel Rici Azarias ${ }^{3}$; Edris Queiroz Lopes $^{14}$ \& Rose Eli Grassi Rici ${ }^{1}$
\end{abstract}

MELO, L. F; RODRIGUES, A. C. B.; CABRERA, M. L.; TURQUETTI, A. O. M.; RUIVO, L. P.; AZARIAS, G. R.; LOPES, E. Q. \& RICI, R. E. G. Analysis of the green turtle esophagus Chelonia mydas (linnaeus, 1758), testudines, cheloniidae. Int. J. Morphol., 37(4):1391-1396, 2019.

SUMMARY: The esophagus is a muscular tube whose function is to transport food from the mouth to the stomach and basically contain the same layers as the rest of the digestive tract. The morphological knowledge of structures involved in basic physiological processes in organisms is extremely important in the acquisition of ecological and evolutionary knowledge about species. This study produces morphological information proving the structures found in the green turtle's esophagus. The animals were dissected according to the methodology used by Wyneken, allowing analysis of external and internal morphological characteristics of the esophagus. The samples were processed for microscopic analysis by light and scanning electron microscopy. It was observed that the esophagus presents thin and conical dermal papillae facing the stomach throughout the mucosa to the gastroesophageal portion, decreasing its size at the end of its extension, covered by a thick keratin layer on keratinized pavement epithelial tissue. It is concluded that the esophagus of Chelonia mydas is covered by a layer of conical keratinized dermal papillae important to exert the mechanical and protective function of the mucosa of this organ, considering that the feeding of these animals is extremely abrasive, besides serving as protection so that the food does not return.

KEY WORDS: Chelonia mydas; Histology; Esophagus; Keratin.

\section{INTRODUCTION}

The green turtle (Chelonia mydas) belongs to the Cheloniidae family and inhabits the tropical and subtropical oceans - Indian, Pacific and Atlantic (Ernest \& Barbour, 1989). It is the species that presents more coastal habits, including estuaries of rivers and lakes (Hirth, 1997), make use of the Brazilian coast for food and spawned on the Red List of the International Union for Conservation of Nature (IUCN).

There are a number of threats to sea turtles, with human action being the main threat. Its name is due to the greenish coloration of its fat, but that is not related to the external appearance (Pritchard \& Trebbau, 1984; Moreira et al., 1995). They assume that this species in its pelagic phase is omnivorous with a strong carnivorous tendency, becoming basically herbivorous in its juvenile phase to adult (Chevalier \& Lartiges, 2001; Fidelis et al., 2005). From 25 to $35 \mathrm{~cm}$ of Curvilinear Length of Carapace (CCC) this species initiates a herbivorous feeding (Bjorndal, 1997).

In chelonians, the gastrointestinal tract is anatomically diverse among the large variety of reptiles, and this fact requires further studies to understand their anatomical specificities (Costa et al., 2010).

The esophagus is a muscular tube whose function is to transport food from the mouth to the stomach and basically contain the same layers as the rest of the digestive tract (Junqueira \& Carneiro, 2013). In the Cheloniidae family, the esophagus descends to only one position inside the

\footnotetext{
${ }^{1}$ University of São Paulo / Faculty of Veterinary Medicine and Animal Science. Department of Anatomy. São Paulo - SP, Brazil.

${ }^{2}$ Federal University of São Carlos - UFSCar, Campus of Buri - SP, Brazil.

${ }^{3}$ Faculty of Dentistry of the APCD - Dental Surgeon, postdoctoral degree in Dentistry of the Faculty FAOA - Paulista Association of Dentist Surgeon. São Paulo - SP, Brazil.

${ }^{4}$ Institute of Marine Biology and Environment - IBIMM. Peruíbe - SP, Brazil.
} 
plastron and leans to the left in an "S" shaped curve to join the stomach. In Dermochelydae, the esophagus is long and extends about half the length of the body before the curve to the left, returning almost to the level of the axilla, where it makes a new curvature and joins the stomach (Wyneken, 2001).

The morphological knowledge of structures involved in basic physiological processes in organisms is extremely important in the acquisition of ecological and evolutionary knowledge about species (Calais Júnior et al., 2016). The study was carried out for the anatomical description and morphological characterization of the esophagus of the green turtle (Chelonia mydas) in order to produce information that allows comparative analysis with other chelonians, as well as to subsidize new studies.

\section{MATERIAL AND METHOD}

Four marine green turtle (Chelonia mydas) specimens were used, found dead on Guaraú beach, Peruíbe - SP and obtained with authorization and licenses approved by ICMBio / SISBio: 50132-1. And approved by the Ethics Committee of the Faculty of Veterinary Medicine and Animal Science, under the protocol: 8336280317 .

The animals were dissected according to the methodology used by Wyneken, allowing the analysis of external and internal morphological characteristics of the esophagus. Samples of the turtle's esophagus were processed for ultramicroscopy, light microscopy (ML) (with HE, Masson, Mallory's Tricomo and Toluidine Blue), and scanning electron microscopy (SEM) samples.

Microscopy of Light: The samples were fixed in $10 \%$ formaldehyde, cut in the medial region of the esophagus, dehydrated in series of ethanols in increasing concentrations (70 to $100 \%$ ) and diaphanized in xylol, with subsequent inclusion in histological paraffin. Slices of $5 \mathrm{~mm}$ thickness were performed on the microtome (Leika, German) and stained with hematoxylin-eosin. And the images were obtained through the Nikon Eclipse E- 800 light microscope from the Advanced Center in Diagnostic Imaging - CADIFMVZ-USP.

Semi-Thin Cuts: The samples were fixed in $10 \%$ formaldehyde, cut in the medial region of the esophagus, dehydrated in a series of ethanols in increasing concentrations (50 to $100 \%$ ), placed in propylene oxide, embedded in Spurr resin. The blocks were sectioned in semithin sections of $300 \mathrm{~nm}$ and stained with toluidine blue. Analyzed on the Nikon Eclipse E- 800 light microscope of the Advanced Center for Diagnostic Imaging - CADIFMVZ-USP.

Scanning Electron Microscopy: The $10 \%$ formalin-fixed samples were dehydrated in increasing series of alcohols in concentrations of $70 \%, 80 \%, 90 \%$ and $100 \%$, dried in a LEICA EM CPD 300 critical point apparatus, glued with carbon paste in metallic bases of (stub) and silver (sputtering) on the EMITECH K550 metallizer, analyzed and photographed in a scanning electron microscope LEO 435VP from the Advanced Center for Diagnostic Imaging (CADIFMVZ-USP).

\section{RESULTS AND DISCUSSION}

In the esophagus of sea turtles is a tubular organ with the presence of horny and keratinized papillae (Fig. 1A). The mucosal papillae are decreasing in size reaching the gastreophageal portion (Fig. 1B).

The digestive system of reptiles contains all structures present in other higher vertebrates (Putterill \& Soley, 2003); however, morphology is directly related to specific eating habits (Silva, 2004). Corroborating with the morphology found in this study, the esophagus presents a tubular organ that shows papillary corneous papillae, whose main function is to transport the food content from the mouth to the stomach, facilitating swallowing and avoiding alimentary reflux, also to act as filtration devices (Porter, 1972; Parsons \& Cameron, 1977; Work, 2000; Pressler et al., 2003; Putterill, \& Soley; Silva; Calais Júnior et al.). This characteristic present in the esophagus of sea turtles is unique among reptiles (Magalhães et al., 2010).

The results confirm the presence of these papillae, disappearing at the transition from the esophagus to the stomach in all animals studied (Santos et al., 1998; Putterill \& Soley; Elliott, 2007).

Wyneken and Pressel et al. (2003) described that the esophagus of the green turtle is devoid of glands, indicating that this organ has only mechanical function in this species (Wyneken). Similar findings were described by another author, Santos et al. for the Amazonian turtle (Podocnemis expansa) and for species of the Pelomedusidae (George \& Castro, 1998). Against the chelonians later study, which characterizes the presence of glands with a probable muco production (Silva).

Light microscopy revealed that the esophagus is covered by a thick keratin layer of the keratinized pavement 


\section{A}
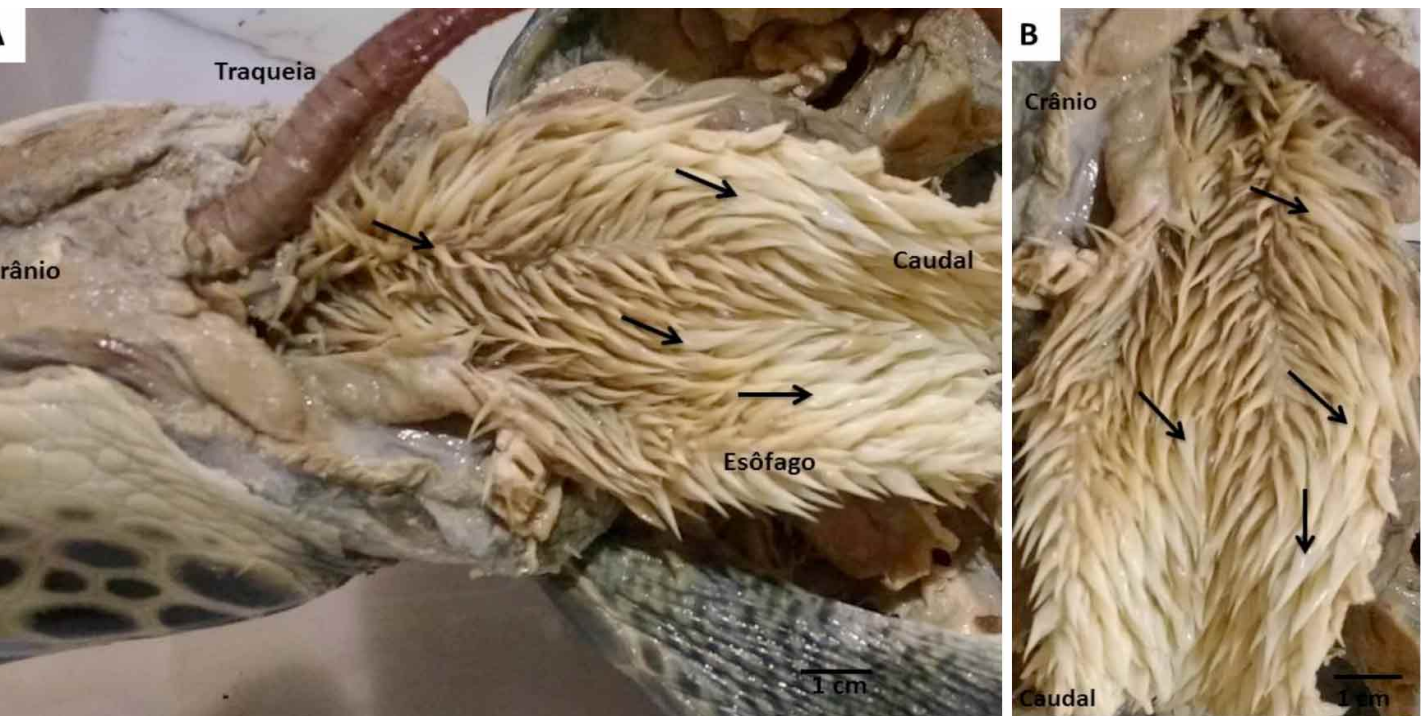

Fig. 1. Esophagus of the sea-turtle Chelonia mydas. A and B: Photographed open esophagus, conical and pointed keratinous papillae (arrows), facing. Bar $1 \mathrm{~cm}$.
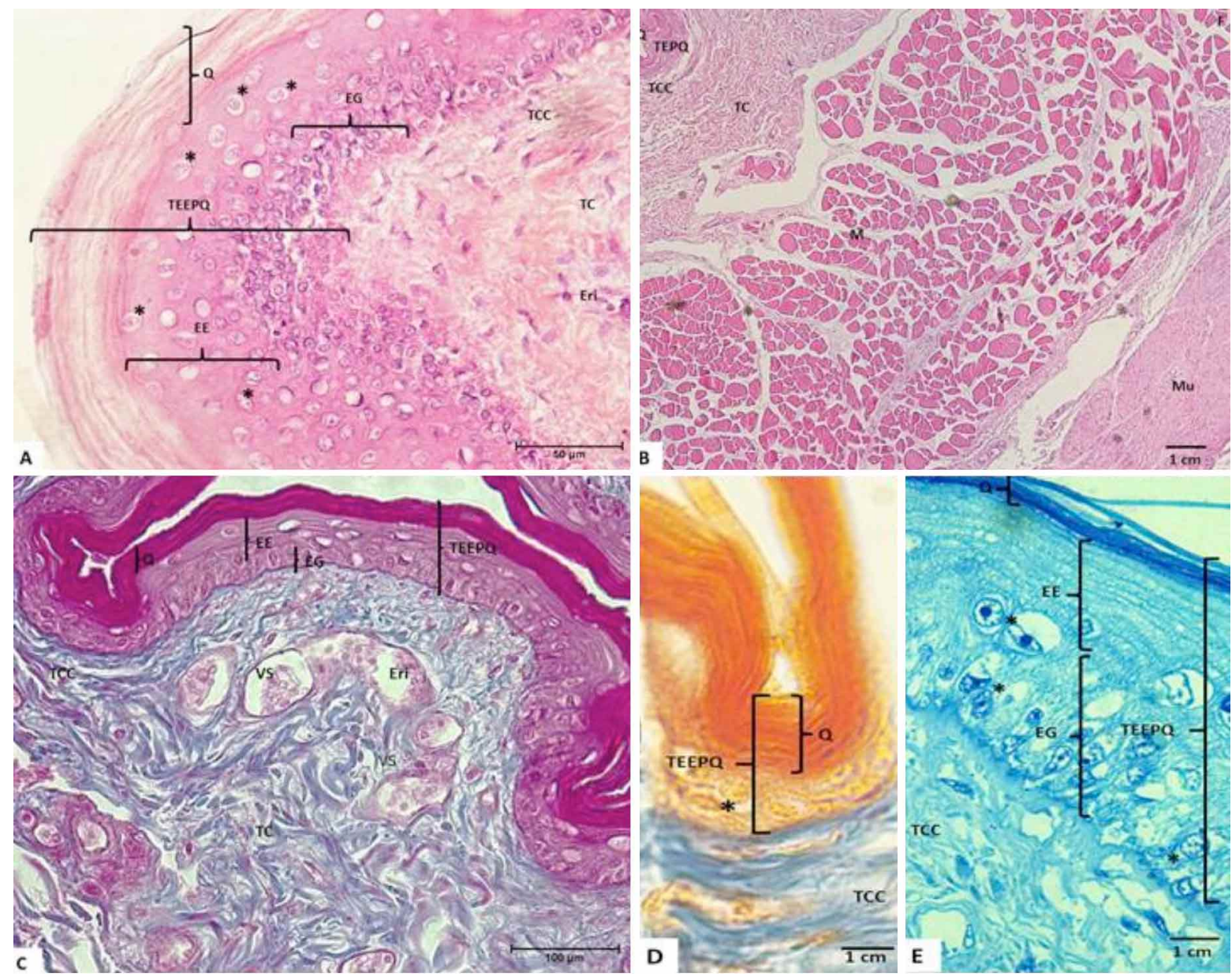

Fig. 2. Microscopy of esophagus of Chelonia mydas. Photomicrography (ML) A-HE, B-HE, C-Masson, D-Mallory, E-Blue

Toluidine. A, B, C, D and E shows all the cell layers that make up esophageal tissue: Keratin layer (Q), keratinized pavement epithelial tissue (TEEPQ), spiny stratum (EE), germinative stratum (VC) and nucleated erythrocytes (Eri), transverse muscle (M), and longitudinal muscle (Mu), vasculature (VS). 
epithelial tissue (TEEPQ), where the keratinocytes, prickly stratum and germinative stratum are present. Below the TEEPQ is noted circular connective tissue and dense connective tissue not modeled with presence of blood vessels with nucleated erythrocytes. In the inferior part we noticed the presence of muscular bundles with slices in the trans-

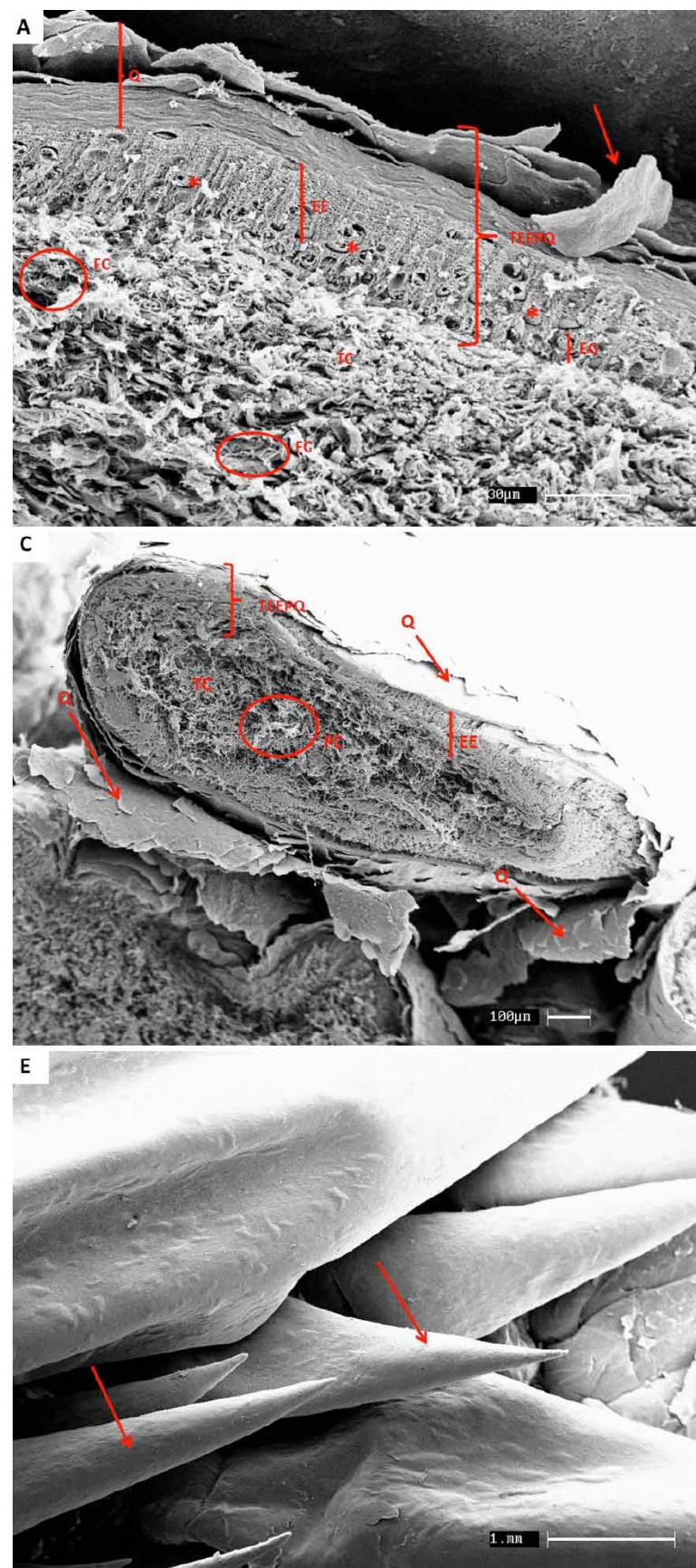

versal and muscular tissue wrapping longitudinally the organ, richly irrigated with blood vessels (Figs. 2A-E).

In the scanning electron microscopy confirmed the findings found in light microscopy observed in Figures 3A-F.

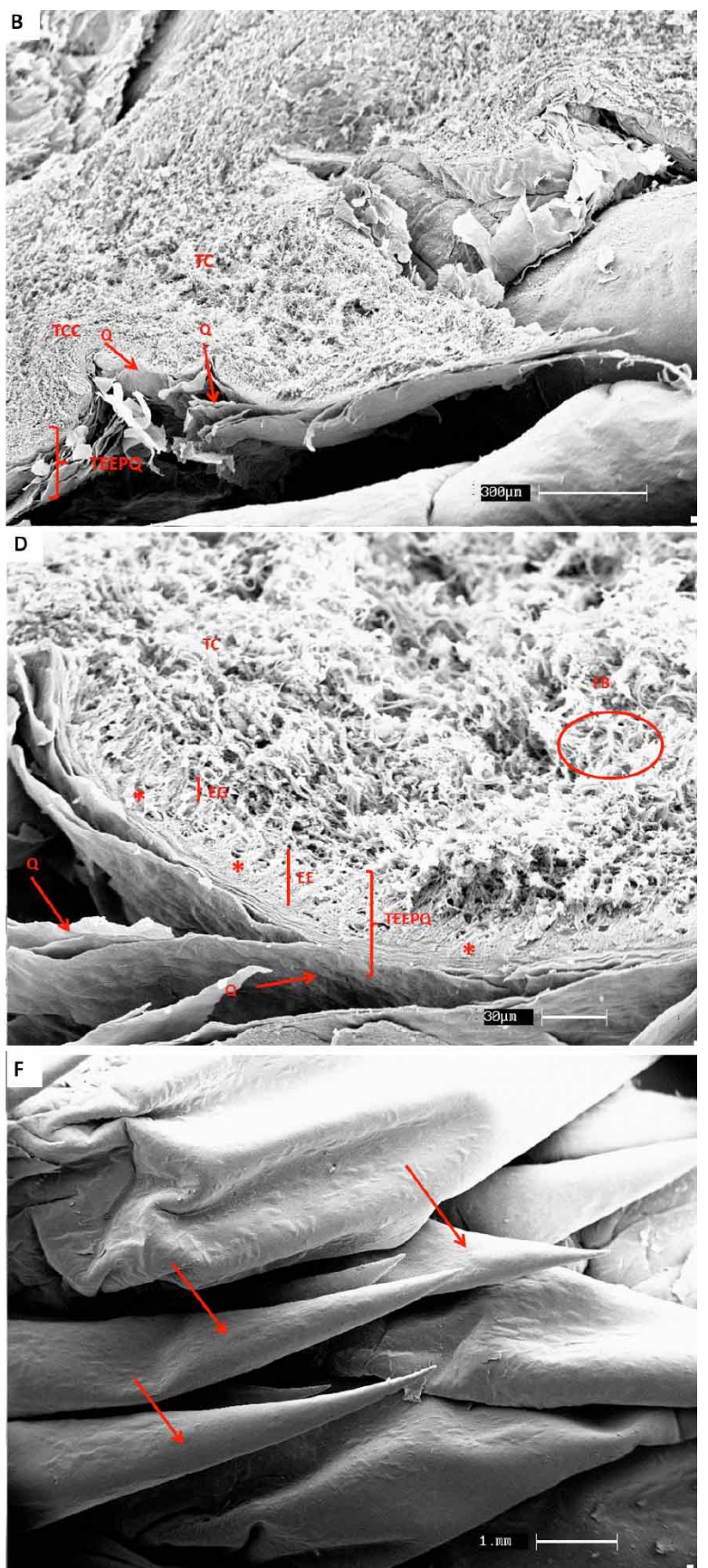

Fig. 3. Electron microscopy of the esophagus and papillas. Scanning electron microscopy photomicrograph, A: keratin (Q) layers, red arrow, keratinized pavement epithelial tissue (TEEPQ), stratum spinosus (EE), germinative stratum (EG), with presence of keratinocytes , circular connective tissue (CBT) and dense unshaped connective tissue (CT), blood vessel (VS) with nucleated erythrocytes (Eri), and collagen fibers (CF). B: longitudinal slice of the papilla, C and D: transversal slice of the papilla. E and F: (Arrows) surface of the projection of the dermis and epidermis, forming dermal papillae with conical and pointed, keratin coated. 
For reptiles, it has generally been described that the esophageal mucosa is lined by epithelium with one or two layers of columnar or cuboidal cells (George \& Castro) however, other researchers have described that the Amazonian turtle (Podocnemis expansa) esophagus had coated mucosa by a prismatic stratified epithelium, (Santos et al.) whereas others, in a study carried out in the Pelomedusidae family, described that they had squamous stratified epithelium confirming our studies where the esophageal lining epithelial tissue is stratified, pavement and keratinized, acting to protect the esophageal mucosa against the friction of food passage and mechanical function and avoiding the return of the food while expelling the water (Vogt et al., 1998), corroborating with our findings.

\section{CONCLUSION}

The esophagus of Chelonia mydas is covered by a layer of keratinized pointed conical dermal papillae important to exert the mechanical and protective function of the mucosa of this organ, considering that the feeding of these animals is extremely abrasive, besides serving as protection so that the food does not return.

ACKNOWLEDGEMENTS Thanks to CAPES financial support. To the Advanced Center in Diagnosis by Image CADI-FMVZ / USP.

MELO, L. F; RODRIGUES, A. C. B.; CABRERA, M. L.; TURQUETTI, A. O. M.; RUIVO, L. P.; AZARIAS, G. R.; LOPES, E. Q. \& RICI, R. E. G. Análisis del esófago de la tortuga verde Chelonia mydas (Linnaeus, 1758), testudines, cheloniidae. Int. J. Morphol., 37(4):1391-1396, 2019.

RESUMEN: El esófago es un tubo muscular cuya función es transportar los alimentos desde la cavidad oral hasta el estómago y, básicamente, contienen las mismas capas que el resto del tracto digestivo. El conocimiento morfológico de las estructuras involucradas en los procesos fisiológicos básicos en los organismos es extremadamente importante en la adquisición de conocimientos ecológicos y evolutivos sobre las especies. Este estudio produce información morfológica que demuestra las estructuras encontradas en el esófago de la tortuga verde. Los animales se disecaron de acuerdo con la metodología utilizada por Wyneken, lo que permitió el análisis de las características morfológicas internas y externas del esófago. Las muestras se procesaron para análisis microscópico mediante microscopía electrónica de barrido y de luz. Se observó que el esófago presenta papilas dérmicas delgadas y cónicas que se enfrentan al estómago a través de la mucosa hasta la porción gastroesofágica, disminuyendo su tamaño al final de su extensión, cubierta por una capa gruesa de queratina sobre el tejido epitelial queratinizado. Se concluye que el esófago de Chelonia mydas está cubierto por una capa de papilas dérmicas queratinizadas cónicas importantes para ejercer la función mecánica y protectora de la mucosa de este órgano, considerando que la alimentación de estos animales es extremadamente abrasiva, además de servir de protección para que la comida no sea devuelta.

PALABRAS CLAVE: Chelonia mydas; Histología; Esófago; Queratina.

\section{REFERENCES}

Bjorndal, K. A. Foraging Ecology and Nutrition of Sea Turtle, In: Lutz, P. L. \& Musick, J. A. (Eds.). The Biology of Sea Turtle. New York, Marine Science Series, 1997. pp.199-231.

Calais Júnior, A.; David, J. A. O. \& Nunes, L. C. Caracterização morfológica do esôfago de tartarugas-verdes (Chelonia mydas). Arq. Bras. Med. Vet. Zootec., 68(1):127-35, 2016.

Chevalier, J. \& Lartiges, A. Les Tortues Marines des Antilles. Paris, Office National de La Chasseet de la Faune Sauvage. CNERA Fauned'Outre Mer, 2001.

Costa, M. F.; Ivar do Sul, J. A.; Silva-Cavalcanti, J. S.; Araújo, M. C.; Spengler, A. \& Tourinho, P. S. On the importance of size of plastic fragments and pellets on the strandline: a snapshot of a Brazilian beach. Environ. Monit. Assess., 168(1-4):299-304, 2010.

Elliott, J. R. Overview of Reptile Biology, Anatomy, and Histology. Infectious Diseases and Pathology of Reptiles. New York, Taylor \& Francis, 2007.

Ernest, C. H. \& Barbour, R. W. Turtles of the World. Washington, Smithsonian Institution Press, 1989.

Fidelis, S. V.; Ballabio, T. A. \& Guebert, F. M. Análise da relação Corporal do Trato Gastrointestinal da Chelonia mydas (Tartaruga Verde) Juvenil do Litoral do Paraná. Vitória, Anais II Congresso Brasileiro de Oceanografia, 2005.

George, L. L. \& Castro, R. R. L. Histologia Comparada. $2^{\text {nd }}$ ed. São Paulo, Roca, 1998.

Hirth, H. F. Synopsis of the Biological Data on the Green Turtle, Chelonia mydas (Linnaeus 1758). Washington, United States Fish and Wildlife Service Biological Report, 1997.

Junqueira, L. C. \& Carneiro, J. Histologia Básica: Texto e Atlas. $10^{\text {th }}$ ed. Rio de Janeiro, Guanabara Koogan, 2013.

Magalhães, M. S.; Freitas, M. L.; da Silva, N. B. \& de Moura, C. E. B. Morfologia do tubo digestório da tartaruga verde (Chelonia mydas). Pesq. Vet. Bras., 30(8):676-84, 2010.

Moreira, L.; Baptistotti, C.; Scalfone, J.; Thomé, J. C. \& de Almeida, A. P. L. S. Occurrence of Chelonia mydas on the island of Trindade, Brazil. Mar. Turt. Newsl., 70(2):2, 1995.

Parsons, T. S. \& Cameron, J. E. The Internal Relief of the Digestive Tract. In: Gans, G. \& Parsons, T. S. (Eds.). Biology of the Reptilia. New York, Academic Press, 1977. pp.159-223.

Porter, K. R. Herpetology. Philadelphia, W. B. Saunders Company, 1972.

Pressler, B. M.; Goodman, R. A.; Harms, C. A., Hawkins, E. C \& Lewbart, G. A. Endoscopic evaluation of the esophagus and stomach in three loggerhead sea turtles (Caretta caretta) and a Malaysian giant turtle (Orlitia borneensis). J. Zoo Wildl. Med., 34(1):88-92, 2003.

Pritchard, P. C. H. \& Trebbau, P. The Turtles of Venezuela. Athens, Society for the Study of Amphibians and Reptiles, 1984.

Putterill, J. F. \& Soley, J. T. General morphology of the oral cavity of the Nile crocodile, Crocodylus niloticus (Laurenti, 1768). I. Palate and gingivae. J. Vet. Res., 70(4):281-97, 2003.

Santos, A. L. Q.; Beletti, M. E. \& Queiroz, R. P. Estudo morfológico do tubo digestivo da tartaruga-da-amazônia Podocnemis expansa. Uberlândia, Universidade Federal de Uberlândia, 1998. 
Silva, N. B. Estudo Morfohistológico do Tubo Digestório de Steindachnerinanotonota Ribeiro 1937 (Characiforme, Curimatidae) e Hopliasmalabaricus Bloch 1794 (Characiformes, Erythrinidae) Dorio Ceará-Mirim em Umari, Distrito de Taipu-RN. Dissertação de Mestrado, Curso de Pós-Graduação em Bioecologia aquática. Natal, Universidade Federal do Rio Grande do Norte, 2004.

Vogt, R. C.; Sever, D. M. \& Moreira, G. Esophageal papillae in Pelomedusid Turtles. J. Herpetol., 32(2):279-82, 1998.

Work, T. M. Manual de Necropsia de Tortugas Marinas para Biologos em Refugios o Areas Remotas. Hawaii, National Wildlife Health Center, Hawaii Field Station, 2000.

Wyneken, J. The Anatomy of Sea Turtles. In: NOAA Technical Memorandum NMFS-SEFSC-470. Miami, U. S. Department of Commerce, National Oceanic and Atmospheric Administration, National Marine Fisheries Service, 2001.
Corresponding author:

Luana Félix de Melo

University of São Paulo

Faculty of Veterinary Medicine and Animal Science

FMVZ / USP

São Paulo

BRAZIL

Email: luanafelix@usp.br

Received: 11-03-2019

Accepted: 17-06-2019 